\title{
片膝しゃがみ位における側方からの外乱刺激に 対する下肢機能の左右の相違
}

\author{
Differences in Right and Left Lower Limb Function in Lateral Perturbation \\ in Half-Knee Squat
}

\author{
加藤 明未1) 佐々木 誠 ${ }^{2}$ \\ Asumi KATO, RPT ${ }^{1)}$, MAKOTO SASAKI, RPT, $\mathrm{PhD}^{2)}$ \\ 1) Department of Rehabilitation, Takenotsuka Rehabilitation Hospital: 4-15-16 Hokima, Adachi-ku, Tokyo 121-0064, Japan. \\ TEL +81 3-5851-1108 \\ 2) Department of Physical Therapy, Graduate School of Health Sciences, Akita University
}

Rigakuryoho Kagaku 25(3): 447-450, 2010. Submitted Dec. 10, 2009. Accepted Jan. 18, 2010.

ABSTRACT: [Purpose] The objective of this study was to clarify the differences in right and left lower limb function. [Subjects] The subjects were 24 healthy students. [Method] In the half-knee squat position, a perturbative stimulus was delivered to the pelvis with a weight. The stimulus was delivered from both sides with the dominant and non-dominant side legs extended, and the center of gravity (COG) sway and the floor reaction force were measured and compared among the four conditions. [Results] Maximum lateral COG sway was significantly smaller when the perturbation was delivered to the dominant side with the dominant leg extended, than when it was delivered to the non-dominant side with the non-dominant leg extended. Also, maximum vertical floor reaction force was significantly smaller when the perturbation was delivered to the dominant side with the non-dominant leg extended, than when it was delivered to the non-dominant side with the dominant leg extended. [Conclusion] The above results suggest that the non-dominant leg is better at coping with perturbation, and show one of the differences in function between the dominant and nondominant legs.

Key words: dominant and non-dominant leg, half-knee squat, perturbative stimulus

要旨：〔目的〕本研究の目的は下肢機能の左右の相違を明らかにすることである。〔対象〕健常学生 24 名とした。〔方 法】片膝しゃがみ位における骨盤に対する重錘による外乱刺激を，利き脚を前に出して利き脚側から加えた場合， 非利き脚を前に出して非利き脚側から加えた場合の 2 種類，利き脚を前に出して非利き脚側から加えた場合，非利 き脚を前に出して利き脚側から加えた場合の 2 種類それぞれで重心動摇と床反力を比較した。〔結果〕重心動摇で はX方向（左右方向）最大振幅が, 非利き脚を前に出して非利き脚側からの外乱刺激を加えた場合より, 利き脚を 前に出して利き脚側からの外乱刺激を加えた場合で有意に小さかった。また，床反力測定值で，Z方向（垂直方向） 最大床反力が, 利き脚を前に出して非利き脚側からの外乱刺激を加えた場合より, 非利き脚を前に出して利き脚側 からの外乱刺激を加えた場合で有意に小さかった。〔結語〕以上の結果より，非利き脚は外乱刺激に対して対処す ることに優れている脚であることが示唆され，利き脚と非利き脚の機能の相違の一部が示された。

キーワード：利き脚と非利き脚，片膝しやがみ位，外乱刺激

1) 竹の塚リハビリテーション病院リハビリテーション部：東京都足立区保木間4-15-16（テ121-0064） TEL 03-5851-1108

2) 秋田大学大学院 医学系研究科保健学専攻理学療法学講座

受付日 2009年12月10日受理日 2010年1月18日 


\section{I.はじめに}

ヒトの身体は, 一見左右対称に見えるが, 内臟器官 のように位置や形状が非対称性を示すものが多い。上 下肢においても，利き手や利き脚のように，機能的な 左右非対称性が報告されており，上肢については，形 態的にも機能的にも一側優位性が確認されている1)。し かし，下肢に関しては，利き脚と非利き脚において足 把持力及び大腿四頭筋力に有意な差は認められないと いった報告2)や両足立ちおよび片脚立ちにおいて, 左足 は右足より支持能力が高い傾向があり, 左足は軸足と して，右足は利き足としてそれぞれ機能していると考 えられるといった報告 ${ }^{3)}$, 下肢の右と左には, 巧緻性, 協調性を要する運動は偏る傾向があるという報告4があ るものの機能の明らかな一側優位性は確認されていな い。下肢の一側優位性があるとすればスポーツ等の高 次な運動においてその影響があると考えられる。

田村ら 5) は, 片膝を立て反対側の膝を床について脚 を完全に屈曲した片膝しゃがみ位からの床上の重量物 を持ち上げる際の床反力の測定から, 下肢の機能の左 右の相違について言及している。これまでの知見より, 田村ら ${ }^{5)}$ が実験に用いた片膝しゃがみ位で，側方から 外乱刺激を加えた際に利き脚よりも非利き脚の方が支 持脚として十分な機能を発揮することができると考え られる。そこで, 片膝しゃがみ位における骨盤に対す る重錘による外乱刺激を, 利き脚を前に出して利き脚 側から加えた場合, 非利き脚を前に出して非利き脚側 から加えた場合の 2 種類, 利き脚を前に出して非利き 脚側から加えた場合, 非利き脚を前に出して利き脚側 から加えた場合の 2 種類それぞれで重心動摇と床反力 を比較した。重心動摇の大きさは外乱刺激に対する安 定性の程度を, 床反力の大きさは外乱刺激に対する緩 衝作用の程度を表すと想定した。これらの比較により， 下肢の機能の左右の相違を明らかにすることを研究目 的とした。

\section{II. 対象と方法}

研究について十分に説明し, 参加に同意を得た学生 24 名（男性 13 名, 女性 11 名, 平均年齢 $23.0 \pm 2.3$ 歳, 平 均身長 $167.0 \pm 9.0 \mathrm{~cm}$, 平均体重 $60.0 \pm 9.8 \mathrm{~kg}$, 平均 $\mathrm{BMI}$ $\left.21.4 \pm 2.0 \mathrm{~kg} / \mathrm{m}^{2}\right)$ を対象者とした。自己申告でボールを 蹴る側の脚を利き脚と規定した。右利き脚は 24 名, 左 利き脚は 0 名であった。利き脚が不明である者はあら かじめ対象から除外した。全ての対象者は6r月以内に
整形外科疾患の既往がなく, かつ, 過去の整形外科疾 患による後遺症がなかった。

片膝しやがみ位における骨盤に対して，利き脚を前 に出して利き脚側からの外乱刺激を加えた場合, 非利 き脚を前に出して非利き脚側からの外乱刺激を加えた 場合の 2 種類, 利き脚を前に出して非利き脚側からの 外乱刺激を加えた場合, 非利き脚を前に出して利き脚 側からの外乱刺激を加えた場合の 2 種類の外乱刺激を 加えた場合の重心動摇と床反力を見た。肢位と刺激を 加える順番はランダムとした。片膝しゃがみ位は, 前 にする脚は足底を接地し，その足尖部と反対側の膝が 一直線になるようにし, 上肢は体幹の前で組んだ姿勢 とした。また, 外乱刺激の方法としては, オーバーヘッ ドフレームから重錘を吊下げ外乱刺激装置を作成し $30^{\circ}$ の角度から $3 \mathrm{~kg}$ の重量の重錘を離して閉眼の対象者の 骨盤に当てた。その際の重心動摇と床反力の測定には アニマ社製のフォースプレートMG-100を使用した。取 り込み周波数を $100 \mathrm{~Hz}$ とし測定時間 20 秒の間に外乱刺 激をランダムに加えた。

利き脚を前に出して利き脚側から加えた場合, 非利 き脚を前に出して非利き脚側から加えた場合の 2 条件, 利き脚を前に出して非利き脚側から加えた場合の 2 条 件それぞれの重心動摇と床反力の比較の検定のために Wilcoxon符号付順位検定を用いた。解析には, StatView version5.0を用い, $\mathrm{p}<0.05$ のとき有意差ありと判定した。

\section{III. 結 果}

重心動摇測定値の比較を表 1 に示す。X方向（左右方 向）最大振幅において, 利き脚を前に出して利き脚側 からの外乱刺激を加えた場合 $(2.331 \pm 0.602 \mathrm{~cm})$ と非 利き脚を前に出して非利き脚側からの外乱刺激を加え た場合 $(2.682 \pm 0.740 \mathrm{~cm})$ の比較で有意差 $(\mathrm{p}<0.05)$ が 認められた。それに対して, 利き脚を前に出して非利 き脚側からの外乱刺激を加えた場合と非利き脚を前に 出して利き脚側からの外乱刺激を加えた場合の比較で は有意差は認められなかった。Y方向（前後方向）最大 振幅において, 利き脚を前に出して利き脚側からの外 乱刺激を加えた場合と非利き脚を前に出して非利き脚 側からの外乱刺激を加えた場合の比較, 利き脚を前に 出して非利き脚側からの外乱刺激を加えた場合と非利 き脚を前に出して利き脚側からの外乱刺激を加えた場 合の比較で, ともに有意な差は得られなかった。

床反力測定值の比較を表 2 に示す。X方向（前後方 向）最大床反力, $\mathrm{Y}$ 方向（左右方向）最大床反力におい 
表1 重心動摇測定值の比較 $(\mathrm{n}=24)$

\begin{tabular}{|c|c|c|}
\hline & 利き脚前の利き脚側からの刺激 & 非利き脚前の非利き脚側からの刺激 \\
\hline X 方向最大振幅（cm） & $2.331 \pm 0.602$ & $2.682 \pm 0.740 *$ \\
\hline \multirow[t]{2}{*}{$\mathrm{Y}$ 方向最大振幅 $(\mathrm{cm})$} & $2.948 \pm 1.446$ & $2.982 \pm 1.022$ \\
\hline & 利き脚前の非利き脚側からの刺激 & 非利き脚前の利き脚側からの刺激 \\
\hline X 万向最大振幅（cm） & $2.072 \pm 0.874$ & $1.660 \pm 1.009$ \\
\hline Y 方向最大振幅 $(\mathrm{cm})$ & $3.670 \pm 1.356$ & $3.793 \pm 1.327$ \\
\hline \multicolumn{3}{|c|}{$\begin{array}{l}\text { 平均值土標準偏差 } \\
\text { Wilcoxon 符号付順位検定, * } \mathrm{p}<0.05 \text { : 利き脚前の利き脚側からの刺激との比較 } \\
\mathrm{X} \text { 方向 : 左右方向, Y 方向 : 前後方向 }\end{array}$} \\
\hline \multicolumn{3}{|c|}{ 表2 床反力測定值の比較 $(\mathrm{n}=24)$} \\
\hline & 利き脚前の利き脚側からの刺激 & 非利き脚前の非利き脚側からの刺激 \\
\hline X 方向最大床反力 $(\mathrm{kg})$ & $4.593 \pm 1.389$ & $5.203 \pm 1.185$ \\
\hline Y 方向最大床反力（kg） & $5.539 \pm 1.517$ & $5.567 \pm 1.916$ \\
\hline \multirow[t]{2}{*}{$\mathrm{Z}$ 方向最大床反力 $(\mathrm{kg})$} & $67.453 \pm 14.348$ & $67.742 \pm 13.742$ \\
\hline & 利き脚前の非利き脚側からの刺激 & 非利き脚前の利き脚側からの刺激 \\
\hline $\mathrm{X}$ 方向最大床反力 $(\mathrm{kg})$ & $3.717 \pm 2.698$ & $3.217 \pm 1.805$ \\
\hline $\mathrm{Y}$ 方向最大床反力（kg） & $5.035 \pm 1.490$ & $5.143 \pm 1.397$ \\
\hline Z 方向最大床反力（kg） & $72.405 \pm 14.445$ & $70.768 \pm 13.356 *$ \\
\hline
\end{tabular}

平均值士標準偏差

Wilcoxon 符号付順位検定, $* \mathrm{p}<0.05$ : 利き脚前の非利き脚側からの刺激との比較

$\mathrm{X}$ 方向 : 前後方向, $\mathrm{Y}$ 方向 : 左右方向, $\mathrm{Z}$ 方向 : 垂直方向

て, 利き脚を前に出して利き脚側からの外乱刺激を加 えた場合と非利き脚を前に出して非利き脚側からの外 乱刺激を加えた場合の比較, 利き脚を前に出して非利 き脚側からの外乱刺激を加えた場合と非利き脚を前に 出して利き脚側からの外乱刺激を加えた場合の比較で, ともに有意な差は得られなかった。Z方向（垂直方向） 最大床反力において, 利き脚を前に出して利き脚側か らの外乱刺激を加えた場合と非利き脚を前に出して非 利き脚側からの外乱刺激を加えた場合の比較で有意差 は認められなかった。それに対して，利き脚を前に出 して非利き脚側からの外乱刺激を加えた場合（72.405 $\pm 14.445 \mathrm{~kg})$ と非利き脚を前に出して利き脚側からの 外乱刺激を加えた場合 $(70.768 \pm 13.356 \mathrm{~kg})$ の比較では 有意差（p<0.05）が認められた。

\section{IV. 考 察}

重心動摇でX方向（左右方向）最大振幅が，非利き 脚を前に出して非利き脚側からの外乱刺激を加えた場 合より, 利き脚を前に出して利き脚側からの外乱刺激
を加えた場合が有意に小さかった。この結果は, 利き 脚側からの外乱刺激に抗したのは，主に膝をついた非 利き脚であったと考えられ，非利き脚のほうが外乱刺 激に対して強い抵抗力を持ち安定していることを示し ている。

床反力測定值でZ方向（垂直方向）最大床反力が, 利 き脚を前に出して非利き脚側からの外乱刺激を加えた 場合より, 非利き脚を前に出して利き脚側からの外乱 刺激を加えた場合が有意に小さかった。X方向（前後 方向）とY方向（左右方向）では有意差がなく，他の方 向へ力が分散したわけではないことがわかる。よって これは, 非利き脚のほうが利き脚よりも外乱刺激に対 して垂直方向の床反力が弱かったことから, 垂直方向 の衝撃を緩衝することにより対処していることを示唆 している。

甲斐ら 2) は利き脚と非利き脚において足把持力及び 大腿四頭筋力に有意な差は認められないと報告をして おり, 以上の結果における差は, 筋力の左右差による ものではないといえる。三上 ${ }^{3)}$ は, 両足立ち・片足立ち における重心面積・重心移動距離の比較検討から, 両 
足立ち及び片足立ちにおいて，左足は右足よりも支持 能力が高い傾向があり, 軸足として機能し, 右足は利 き脚として機能すると考えられるとしている。また， 平沢6) も両足立ち, 片足立ちの重心動摇の測定から静 的支持能力においては左脚が右脚よりも優れていると しており，今回の結果はこれらを支持するものである。

以上より, 非利き脚は利き脚と比較して外乱刺激に 対処することに優れた脚であることが示唆された。今 回の研究により, 利き脚と非利き脚の機能の相違の一 部が示され, 動的支持能力においても非利き脚が利き 脚よりも優れていることが示唆された。

\section{引用文献}

1) 村田 伸, 松尾奈々, 溝田勝彦: 上下肢の一側優位性に関寸 る研究. 西九州リハビリテーション研究, 2008, 1: 11-14.

2) 甲斐義浩, 村田 伸, 田中真一: 利き脚と非利き足における 足把持力および大腿四頭筋力の比較. 理学療法科学, 2007 , 22(3): 365-368.

3) 三上一貴 : 軸足 - 利き足の検討. 理学療法研究, 1999, (16): 15-18.

4) 松田宣昭, 佐藤英俊, 磯 毅彦・他: 下肢運動能力における 左右差の比較. 理学療法学, 1984, 11(Suppl): 108.

5) 田村 陽, 三浦早織, 池田光範・他 : 片膝しゃがみ位からの 重量物持ち上げ動作に対する下肢の機能の左右の相違の影 響. 理学療法科学, 2010, 25(1): 37-70.

6）平沢彌一郎: Stasiologyからみた右足と左足. 神経進歩, 1980, 24(3): 623-633. 